\title{
RECOVERIES OF RED-TAILED HAWKS BANDED IN SASKATCHEWAN
}

\author{
by C. Stuart Houston, 863 University Drive, Saskatoon
}

With this issue begins a series of maps showing recoveries of birds banded in Saskatchewan. These maps tre compiled from data on a computer "print-out" of all recoveries of Saskatchewan - banded birds (excluding waterfowl), supplied by the U.S. Fish ind Wildlife Service, through the Canadian Wildlife Service. It will be Feen that the efforts of many Saskatchewan banders over a period of nearly 45 years collectively provide a rreat deal of information about the movements and longevity of certain pecies of Saskatchewan birds. The first recoveries were from birds banded in 1923 by R. H. Carter of Muscow and Reuben Lloyd of Davidson; George Lang of Indian Head banded 22 birds in 1923 but had his first recovories from birds banded in 1924. As amateurs, these men banded what and when they could, in essentially random fashion at first, but later giving somewhat more attention to certain species.

On the map I have used a square to represent each "direct recovery", obtained the same year as the bird was banded, in its first migration. Each circle represents a recovery obtained in a subsequent year.

The Fish \& Wildlife Service lists localities very accurately to the nearest ten minutes of latitude and longitude, each such "quadrant" representing in Saskatchewan an area of about 11 by 7 miles. Thus $532-1040$ means $53^{\circ} 20^{\prime}$ north latitude and $104^{\circ}$ $00^{\prime}$ west longitude. This allows quick and accurate location on a map without the time-consuming process of locating place names.

A remarkably high recovery rate has been obtained for Red-tailed Hawks banded in Saskatchewan. For example, R. H. Carter, Jr. had 16 recoveries from only 40 hawks banded, a rate of $40 \%$. Philip Siemens of Hepburn banded 12 redtails and had four recoveries, or $33.3 \%$. Nipawin banding of 29 redtails by Street and Matthews yielded eight recoveries, for a rate of $27.6 \%$. Of the first 36 redtails I barded to 1959 , there were five recoveries or nearly $14 \%$. Likely the higher recovery rates in the earlier years reflected heavier shooting pressure, which has gradually decreased, perhaps in part due to education of the public as to the value of hawks. By scanning the table, one can see that 34 of 48 recoveries were by shooting, and this included almost all the hawks prior to 1940. Recovery rates of this magnitude are rarely encountered, except for Canvasback and Redhead ducks.

The other unusual feature, compared to other species, is the decreased number of "direct recoveries" and the corresponding increase in the number of redtails that live to a relatively advanced age. Note that the two Carters had two recovered at 14 years, one at 12 years, two at 11 years and three at seven years. These apparently include the records for longevity for this species: the redtail shot at Ethel, Louisiana after 13 years, 6 months, 20 days was listed in The Ring, the international journal of bird banding, in February 1963 as the oldest known banded bird of this species. Actually, J. R. Carter's bird shot at Lemberg, Saskatchewan, was slightly older: 13 years, 9 months, 29 days. (These birds are placed in the "14 year" category of the U.S. Fish \& Wildlife Service on the basis of the calendar year; a bird shot January 2 may only be 8 months old, but is no longer "direct" and moves up into the "one year" category). 


\section{Banded by John R. Carter, Muscow, Sask. (504-1035):}

Banded June 30/29. Trapped mid-Jan./34 (5 yrs.) in Arkansas (360-0940). Banded June 30/29. Shot mid-Nov./36 (7 yrs.) in Mississippi (331-0902).

Banded June 30/29. Shot Sept. 22/39 (direct) in North Dakota (481-0992). Banded July 2/39. Shot April 1/40 (1 $\mathrm{yr}$.) in North Dakota (462-0964). Banded July 14/40. Shot March 6/45 (5 yr.) in Iowa (41x-092x). Banded July 14/40. Shot May 13/54 (14 yr.) Lemberg, Sask. (504-1031).

Banded by R. H. Carter, Jr. Muscow, Sask. (504-1035) (40 banded): Banded July 1/23. Shot Oct. 31/23 (direct) Randall, Iowa (421-0933). Banded June 29/24. Shot Jan. 17/38 (14 yr.) Ethel, La. (304-0910).

Banded June 30/24. Found dead Aug. 15/41 (7 yr.) Balcarres, Sask. (504-1033) Banded June 30/24. Unknown; early Mar./36 (12 yr.) Rose, Kan., (374-0954) Banded June 20/26. Shot Jan. 23/37 (11 yr.) Burton, Texas (301-0963). Banded June 20/26. Shot Oct. 12/26 (direct) Butterfield, Minn. (435-0944). Banded July $3 / 27$. Banded July $3 / 27$. Banded July $3 / 27$. Banded July $3 / 27$. Banded July $10 / 27$. Banded July 10/27. Banded July $1 / 42$. Banded July $4 / 48$. Banded July $4 / 48$. Banded July $7 / 59$.

Shot early Feb./34 (7 yr.) Iota, La. (302-0922).

Captured Nov. 24/27 (direct) Chelsea, Okla. (363-0952) Shot Nov. $3 / 27$ (direct) Brumley, Missouri (380-0922). Shot early Jan./38 (11 yr.) Greenwood, Ark. (351-0941). Shot Nov. 8/28 (1 yr.) Tulsa, Okla. (361-0955).

Shot Nov. 6/30 (3 yr.) Chetopa, Kansas (370-0950).

Shot March 31/45 (3 yr.) Hope, N.D. (471-0973).

Shot Feb. 21/54 (6 yr.) Longview, Texas (322-0944).

Shot Nov. $1 / 48$ (direct) McCune, Kansas (372-0950).

Shot Aug. 17/59 (direct) Ft. Qu'Appelle, Sask. (504-1034).

Banded by Philip Siemens, Hepburn, Sask. (523-1064): (12 banded)

Banded June 23/30. Shot Dec. 30/30 (direct) in Texas (294-0970).

Banded July 7/31. Shot Nov. 1/31 (direct) in Iowa (423-0943).

Banded July 7/31. Shot Jan. 24/32 (1 yr.) in Texas (281-0974).

Banded Aug. 3/33. Shot Dec. 28/33 (direct) in Oklahoma (340-0953).

Banded by Robert M. Blakeley, Canora, Sask. (515-1022) :

Banded June 13/29. Shot Nov. 23/29 (direct) in Texas (292-0954).

Banded June 13/29. Shot Feb. 13/32 (3 yr.) in Texas (284-0970).

Banded by Mrs. F. Wickencamp, Stenen, Sask. (515-1022):

Banded June 14/33. Shot Oct. 15/33 (direct) in Texas (294-0952).

Banded by C. Stuart Houston, near Yorkton, Sask. (505to511-1020to1024):

Banded at 511-1023, June 8/46. Shot Feb. 28/48 (2 yr) Kaplan, La. (300-0921).

Banded at 511-1023, June 8/59. Found dead Mar. 25/60 (1 yr.) Lucedale, Miss. (305-0883).

Banded June 15/59. Shot Nov. 26/63 (4 yr.) McCrory, Ark. (351-0911).

Banded July 1/59. Killed by auto Sept. 20/59 (direct) Russell, Man.

Banded July $1 / 59$. (504-1011).

Banded June 29/60. Shot Dec. 23/60 (direct) in Louisiana (301-0920).

Banded June 29/60. Shot Feb. 6/61 (1 yr.) Oxford, Alabama (333-0855).

Banded by C. Stuart Houston near Ruddell, Sask. (523-1075):

Banded June 14/64. Unknown; hunting season/64 (direct) in Minn. (434-0942).

Banded by Glen A. Fox near Cando, Sask. (524-1075):

Banded Aug. 11/60. Found dead Jan. 17/61 (1 yr.) in Alabama (322-0861).

Banded by Maurice G. Street, Nipawin (532-1040 and 531-1040) (22 banded):

Banded June 28/46. Shot before Aug. 3/46 (direct) Nipawin, Sask. (531-1035).

Banded June 30/46. Shot mid-June/47 (1 yr.) Emmett Co., Iowa (431-0944). 
anded June 16/47. In fox trap Nov. 11/47 (direct) Kenosha, Wis. (423-0874). inded June 27/47. Shot Aug. 17/47 (direct) Nipawin, Sask. (532-1040). anded June 27/47. Shot Dec. 16/48 (1 yr.) Chanute, Kans. (374-0953). anded July 14/50. Shot Nov. $12 / 50$ (direct) Metz, Missouri (380-0942). anded, Walter \& Billy Matthews, Nipawin (531-1040 and 532-1040) (7 banded): anded June 20/50. Found dead before Oct. 13/50 (direct) Neelin, Man. (491-0992).

anded July 1/52. Unknown, before Jan. 20/53 (1 yr.) Onaga, Kan. (393-0961).

anded by M. Ross Lein, Moose Mountain, Sask. (495-1023 and 494-1022):

anded June 22/65. Skeleton found before Oct. 18/65, Carlyle, Sask. (493-1021). anded June 23/65. Caught by hand before Dec. 4/65 in Kansas (375-0975).

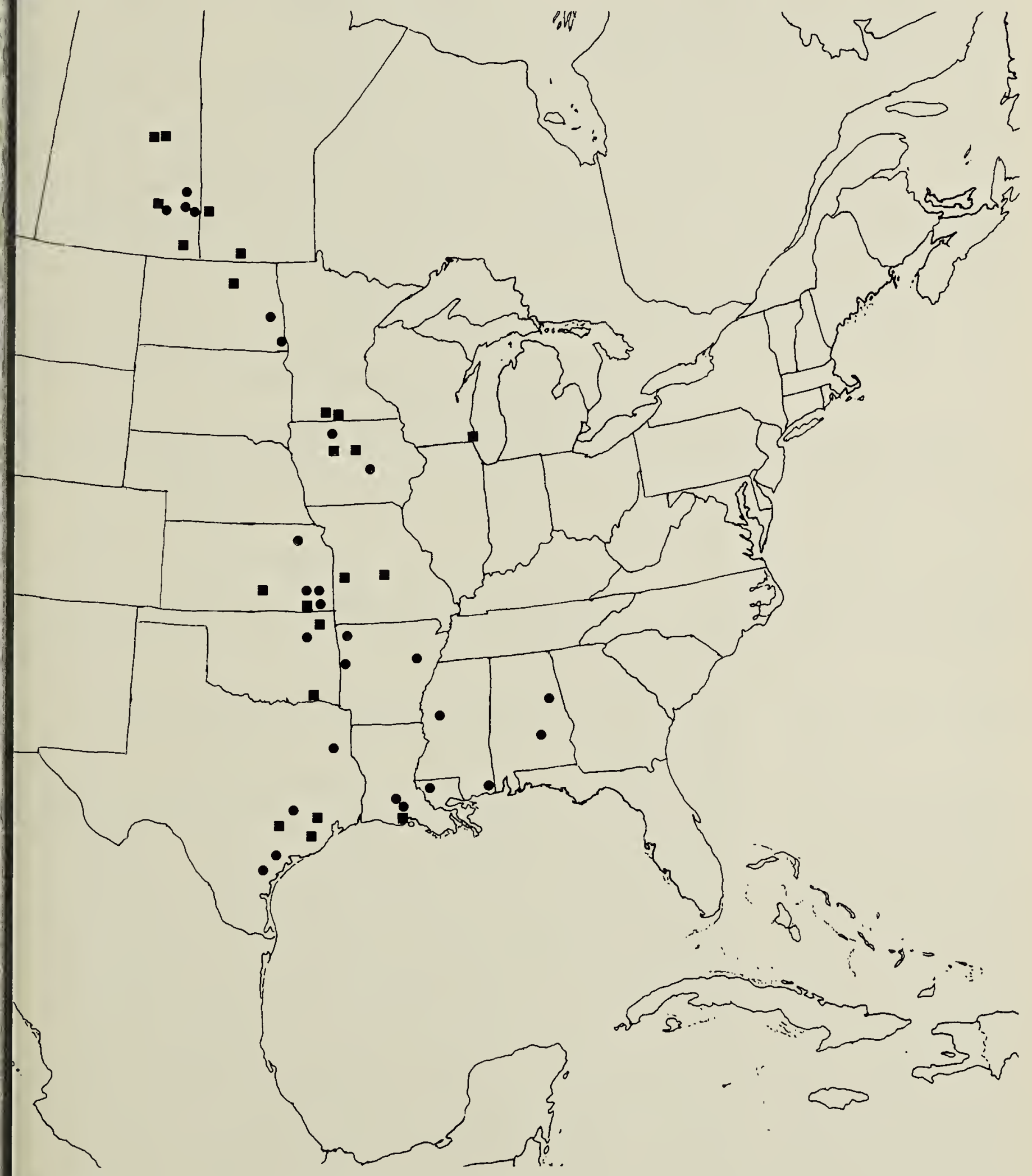

Cecoveries of Red-tailed Hawks banded in Saskatchewan

Note: Squares represent direct recoveries (same year). Circles represent subsequent years. 